\title{
Preliminary study on greywater treatment using water hyacinth
}

\author{
Rajnikant Prasad ${ }^{1} \cdot$ Dayanand Sharma $^{2} \cdot$ Kunwar D Yadav $^{1} \cdot$ Hussameldin Ibrahim ${ }^{3}[$
}

Received: 10 November 2020 / Accepted: 4 May 2021 / Published online: 21 May 2021

(c) The Author(s) 2021

\begin{abstract}
Greywater constitutes a major portion of wastewater generated from domestic units. Greywater treatment through a natural treatment system provides a sustainable method of wastewater management. The objective of this study was to evaluate the potential of water hyacinth as phytoremediation aquatic microphytes for greywater treatment based on optimum growth and harvesting frequency. The treatment system was operated in continuous mode for 30 days. The physicochemical properties of treated greywater and physical characteristics of water hyacinth were determined. The physiochemical parameters of the influent greywater: water temperature $\left(23.1-24.9^{\circ} \mathrm{C}\right), \mathrm{pH}(6.94-7.94)$, total dissolved solids (192-648 $\left.\mathrm{mg} / \mathrm{L}\right)$, turbidity (9.8-49.9 NTU), chemical oxygen demand (51.2-179.2 mg/L), ammonium-nitrogen (2.8-6.16 mg/L), and phosphate-phosphorous $(0.45-1.168 \mathrm{mg} / \mathrm{L})$. The results showed an average removal of ammonium-nitrogen, phosphate-phosphorous, and chemical oxygen demand of $63.26 \pm 10.47 \%, 61.96 \pm 12.11 \%$, and $51.91 \pm 5.32 \%$, respectively. A $75 \%$ increase in the water hyacinth biomass was observed during the study which may be attributed to the dense roots, hyperaccumulative properties, and the rapid growth rate of water hyacinth. A harvesting interval of 15-20 days was recommended for phytoremediation of greywater for efficient treatment performance. However, feasible harvesting methods need to be developed for removing only matured mother plants, leaving baby water hyacinth in the treatment system. Water hyacinth found to be a potential phytoremediation plant for greywater treatment, providing consistent quality of treated water.
\end{abstract}

Keywords Eichhornia crassipes $\cdot$ Greywater $\cdot$ Phytoremediation $\cdot$ Harvesting

\section{Introduction}

In recent years, climate change and the limited availability of freshwater resources have caused worldwide water crises. Also, the increase in living standards and urbanization is causing an increase in water contamination (Ahamed et al. 2016; Barkoula et al. 2008; Inamuddin and Ismail 2010). Due to the limited availability of freshwater resources and to satisfy the ever-increasing water demand, the recycling and reuse of treated greywater for non-potable purposes

Hussameldin Ibrahim

hussameldin.ibrahim@uregina.ca

1 Civil Engineering Department, Sardar Vallabhbhai National Institute of Technology, Surat, Gujarat 395007, India

2 Civil Engineering Department, National Institute of Technology Patna, Ashok Rajpath, Mahendru, Patna, Bihar 800005, India

3 Process Systems Engineering, Faculty of Engineering and Applied Science, Clean Energy Technologies Research Institute, University of Regina, 3737 Wascana Parkway, Regina S4S 0A2, Canada becomes important. Therefore, low energy, low cost, easy to maintain, sustainable, and reliable greywater treatment technique is sought. The use of potable water for non-drinking purposes like gardening, toilet flushing, fire-fighting, and vehicle washing adds unnecessary strain on the already limited drinking water supply. The water requirements for non-drinking purposes can be met using treated greywater which accounts for two-thirds of the household wastewater generation (Friedler and Hadari 2006). The amount of greywater produced in domestic units varies from fifteen liters to several hundred liters per person depending upon the economics, geographical location, climate condition, and consumer behavior (Oteng-Peprah et al. 2018). Compared to blackwater, greywater has a low content of organic matter, nutrients, and pathogens. Greywater reuse can play a vital role in converting wastewater to usable water for its use in gardening, toilet flushing, and similar non-drinking purposes. Several treatment technologies have been investigated by researchers, which include physicochemical, biological, and natural treatments. Physical treatment is mainly a filtration-based process while biological treatment 
involves aerated bioreactor and biological aerated filters. Advanced technology like MBRs and cheap technology like red beds have been investigated. Chemical treatment process like chemical coagulation and electrocoagulation was also studied. Among the various natural treatment measures, phytoremediation gained popularity due to low operating and maintenance costs and being environmentfriendly. Phytoremediation is a process in which plants are used to remove (transfer, mitigate, stabilize, or degrade) contaminants by the interaction between soil, water, plant, and microorganisms in wastewater treatment. The type of plants plays a key role in the efficacy of this treatment method. The plant must have rapid growth rate, high nutrient absorbing capacity, high biomass content, and easy to harvest. Different plant types like water lettuce, duckweed, and vetiver grass have been studied to treat wastewater from different sources (Barkoula et al. 2008; Gupta et al. 2012; Mohammad et al. 2015; Shah et al. 2014; Sooknah and Wilkie 2004). Aquatic plants like duckweed, water lettuce, canna lily, water hyacinth, and reed are preferred because they can directly absorb wastewater and do not require land for growth (Cheng and Stomp 2009). Eichhornia crassipes plant (ECP), commonly known as water hyacinth, belongs to the monocotyledonous family Pontederiaceae, a freefloating aquatic plant native to South America. The plant is considered invasive due to its rapid growth rate. It proliferates, having a biomass doubling time of 5-15 days (Agarry et al. 2018). ECP is often considered a problematic weed, uncontrollable if not appropriately managed, and possess a high risk to the water bodies and the aquatic ecosystem. It obstructs the natural flow of water, smooth navigation, fishing, and hydroelectric power generation. However, due to its physiological characteristics like a dense root system, hyperaccumulation capacity for nutrients, and survival in a wide range of environmental conditions, ECP has been used for phytoremediation of wastewater (Jayaweera and Kasturiarachchi 2004). It has a long and dense root system making it more efficient compared to rooted emergent plants. The successful use of ECP for wastewater treatment depends on the controlled growth, proper harvest, and disposal option. Qin et al. (2016) explored the in situ use of ECP as phytoremediation for nutrient removal from domestic sewage ponds. Upon removal of nutrients, ECP can be harvested. Then, the harvested biomass can then be used for soil enrichment, energy production in the form of bioethanol (Ganguly et al. 2012), briquette (Davies and Abolude 2013), biogas (Priya et al. 2018), and as a fertilizer (Gajalakshmi and Abbasi 2002). Also, ECP has been shown to be an excellent color removal (Prasad and Yadav 2020) and for eutrophic water treatment (Gao et al. 2014). However, studies of phytoremediation using ECP for greywater treatment for optimum nutrient removal and harvesting time for continuous operations are limited in the open literature. Therefore, the present study, for the first time in the open literature, aims to determine the potential of using ECP for greywater treatment and harvesting time required for optimum nutrient removal. The plant characteristics like biomass growth rate, root length, and shoot length were also determined and correlated to the ECP's nutrient removal performance.

\section{Materials and methods}

\section{Location}

This study was conducted in the laboratory scale system located in the old classroom complex building of the Civil Engineering Department, Sardar Vallabhbhai National Institute of Technology (SVNIT), Surat, Gujarat, India (latitude $21.1643^{\circ} \mathrm{N}$, longitude $72.784^{\circ} \mathrm{E}$ ).

\section{Experimental reactor}

Figure 1 shows the elevation and plan view of the greywater treatment experimental setup used in this study. It consists of a rectangular reactor with one influent (inlet) pipe at the top and one effluent (outlet) pipe to the bottom of the reactor. Perforated pipes were fitted at the influent and effluent of the reactor. The surface area of the reactor was $0.3 \mathrm{~m}^{2}(1 \mathrm{~m}$ length, $0.3 \mathrm{~m}$ width, and $0.3 \mathrm{~m}$ depth), and water volume of $80 \mathrm{~L}$ ( $0.27 \mathrm{~m}$ water depth). An overhead tank (1.1 m length, $0.73 \mathrm{~m}$ width, and $0.44 \mathrm{~m}$ depth) with a capacity of $250 \mathrm{~L}$ was provided, which provides a continuous feed of greywater to the influent of the reactor. A mixer was attached at the top of the overhead tank, which continuously mixes the greywater and prevents the settling of the suspended particles. The flow of greywater to the reactor was controlled using a control valve provided in the overhead tank. A similar reactor was used for ECP physical characterization with the same flow rate, water depth, and plant density parallel to the experimental reactor.

\section{Greywater and experimental plant}

The greywater was collected from the hostel building located on the campus of SVNIT, Surat, India. A greywater collection unit of $1000 \mathrm{~L}$ compacity was installed for collection from the shower, hand basin, and cloth washing area. The excess greywater is automatically discharged into the drainage pipe using the drain valve provided at the top of the greywater collection unit. Floating plant, ECP was collected from a pond at Hazira, Surat. Healthy baby plants with a length of $15 \mathrm{~cm}$ above root were collected. The average weight of the individual plant was $100 \pm 20 \mathrm{~g}$. Collected plants were stored in a separate tank, which acted as a plant bank for further studies. 
Fig. 1 Sectional elevation and plan view of the experimental setup for greywater treatment

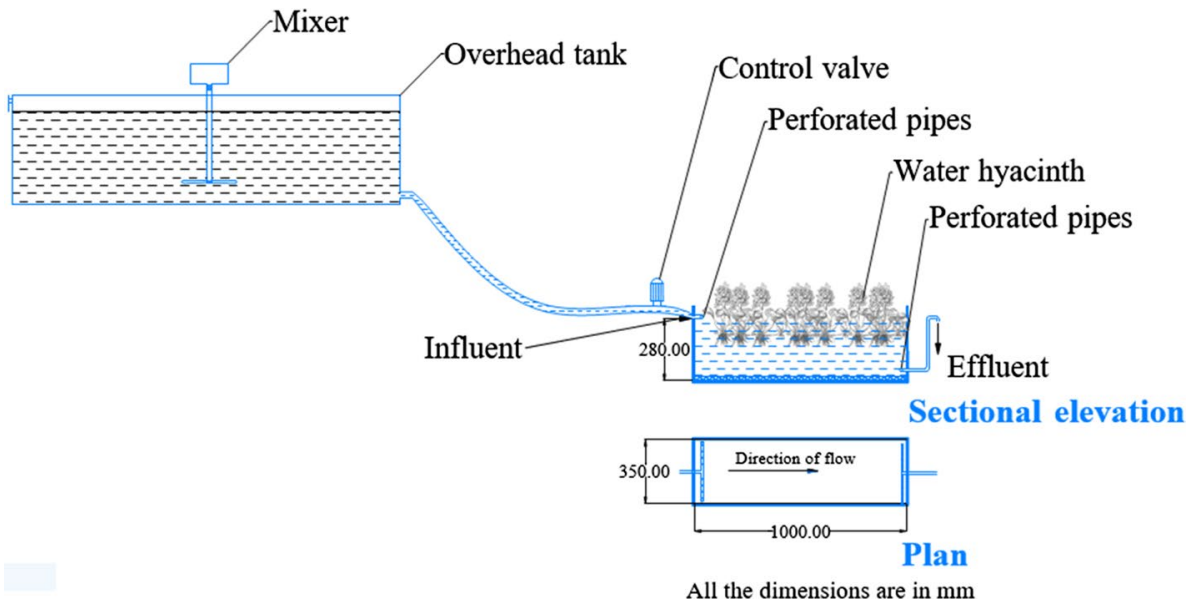

\section{Operation and sampling}

A similar-sized plant was used $(100 \pm 20 \mathrm{~g})$ with a total weight of $2 \mathrm{~kg}$ (wet). The reactor was fed with greywater continuously from the inlet (Fig. 1), and effluent was collected using siphon action synchronous with the flow from the outlet. The hydraulic loading rate during the experiment was $0.26 \mathrm{~m} / \mathrm{day}$, with a retention time of $24 \mathrm{~h}$. The experiment lasted for 30 days. Water samples were collected (daily between 9:30 and 10:00 am), stored in an ice container, and immediately transported to the laboratory for analysis. The characteristics of ECP were determined at a 5-day interval and expressed in fresh weight $(\mathrm{kg})$. The plant was harvested and weighed using a portable electronic balance. The shoot and root lengths were measured using a scale ruler. After measuring, the plant was placed back into the reactor.

\section{Sample analysis}

Greywater samples of the influent and effluent were analyzed for water temperature, $\mathrm{pH}$, TDS, turbidity, chemical oxygen demand (COD), ammonium-nitrogen $\left(\mathrm{NH}_{4}-\mathrm{N}\right)$, and phosphate-phosphorous $\left(\mathrm{PO}_{4}\right)^{3-}-\mathrm{P}$. The $\mathrm{pH}$, TDS, and temperature were measured using a $\mathrm{pH}$ and $\mathrm{EC}$ meter (Hanna Instruments, HI98129, Romania). Turbidity was measured using a turbidity meter (turbidity meter -135 , Systronics). $\mathrm{COD}, \mathrm{NH}_{4}-\mathrm{N}$, and $\left(\mathrm{PO}_{4}\right)^{3-}-\mathrm{P}$ were analyzed using standard methods (APHA 2012). For analysis, water samples (approximately 1L) were collected from the influent (inlet) and effluent (outlet) of the treatment system. Biomass wet weight $(\mathrm{kg})$ of ECP was analyzed at the beginning and the end of the study. Treatment efficiency was calculated using Eq. (1):

Removal efficiency $(\%)=\frac{\mathrm{C}_{\mathrm{i}}-\mathrm{C}_{\mathrm{e}}}{\mathrm{C}_{\mathrm{i}}} \times 100$

where $\mathrm{C}_{\mathrm{i}}$ and $\mathrm{C}_{\mathrm{e}}$ are influent and effluent concentration in $\mathrm{mg} / \mathrm{L}$. Statistical analysis of the obtained result was performed using IBM SPSS 17.0. The data tested with one-way analysis of variance (ANOVA) to find the statistical difference between influent and effluent parameters.

\section{Results and discussion}

The minimum-maximum and average values of the influent greywater characteristics are shown in Table 1. Variations in process parameters (temperature, $\mathrm{pH}$, TDS, turbidity, $\mathrm{COD}$, and nutrients) in the influent and effluent during the
Table 1 Untreated greywater characteristics

\begin{tabular}{lllcc}
\hline Parameter & Unit & $\mathrm{N}^{*}$ & Min-max & Average \pm SD \\
\hline Temperature & ${ }^{\circ} \mathrm{C}$ & 30 & $23.4-24.7$ & $23.91 \pm 0.42$ \\
$\mathrm{pH}$ & - & 30 & $7.26-7.45$ & $7.35 \pm 0.05$ \\
Total dissolved solids & $\mathrm{mg} / \mathrm{L}$ & 30 & $249-329$ & $285.47 \pm 19.12$ \\
Turbidity & $\mathrm{NTU}$ & 30 & $28-42.8$ & $29.75 \pm 9.895$ \\
Chemical oxygen demand & $\mathrm{mg} / \mathrm{L}$ & 30 & $88.8-141.6$ & $113.86 \pm 15.61$ \\
Ammonium-nitrogen $\left(\mathrm{NH}_{4}-\mathrm{N}\right)$ & $\mathrm{mg} / \mathrm{L}$ & 30 & $3.36-5.32$ & $4.52 \pm 0.55$ \\
Phosphate-phosphorous $\left(\mathrm{PO}_{4}\right)^{3-}-\mathrm{P}$ & $\mathrm{mg} / \mathrm{L}$ & 30 & $0.77-1.17$ & $0.96 \pm 0.12$ \\
\hline
\end{tabular}

* No. of samples 
Fig. 2 Temporal variations in the physicochemical properties of a water temperature; $\mathbf{b} \mathrm{pH}$; $\mathbf{c}$ turbidity; $\mathbf{d}$ TDS; and e COD of influent and effluent greywater samples

sampling period were observed in discussed in the following sections.

\section{Physicochemical properties of the water sample}

The physicochemical properties of greywater from the reactor influent and effluent are shown in Fig. 2. Variations in all parameters when comparing inlet and outlet greywater properties were of significance $(p<0.05)$. As shown from Fig. 2a) the greywater temperature for the influent and the effluent streams were in the range of $23.4-24.7{ }^{\circ} \mathrm{C}$ and $23-24.5^{\circ} \mathrm{C}$, respectively. Also, the average influent and effluent water temperatures were $23.91 \pm 0.42{ }^{\circ} \mathrm{C}$ and $23.58 \pm 0.44{ }^{\circ} \mathrm{C}$, respectively. The temperature of untreated and treated greywater did not change substantially during the duration of the experimental run. The slightly lower temperature in the effluent stream can be attributed to the presence of ECP (Hill and Payton 2000). The minimum and maximum atmospheric temperatures of $19.6{ }^{\circ} \mathrm{C}$ and 34.1 ${ }^{\circ} \mathrm{C}$ are considered as most favorable for ECP growth and reproduction (Dersseh et al. 2019; El-Gendy et al. 2004). Higher growth rate and reproduction will consequently result in the absorption of more nutrients from greywater. Changes in $\mathrm{pH}$ values are shown in Fig. 2b. The average $\mathrm{pH}$ of the influent and effluent greywater was $7.33 \pm 0.05$ and $7.28 \pm 0.06$, respectively. Overall, the $\mathrm{pH}$ values of effluent water were slightly lower than the influent. Kadlec and Wallace (2009) reported $\mathrm{pH}$ of $6.5-8.5$ is required for the denitrification process in the treatment system, whereas for ECP growth $\mathrm{pH}$ of 4-8 is necessary for optimum growth (El-Gendy et al. 2004). The average turbidity of the influent greywater was $34.73 \pm 4.13 \mathrm{NTU}$ which was reduced to $3.16 \pm 2.28 \mathrm{NTU}$ at the effluent, Fig. 2c. The TDS of the influent was $285.47 \pm 19.12 \mathrm{mg} / \mathrm{L}$ and for the effluent, it was $259.0 \pm 16.35 \mathrm{mg} / \mathrm{L}$ as shown from Fig. $2 \mathrm{~d}$. The COD value of the influent was $113.82 \pm 15.61 \mathrm{mg} / \mathrm{L}$ reduced to $54.25 \pm 14.36 \mathrm{mg} / \mathrm{L}$ by the effluent as shown in Fig. 2e Compared to the influent greywater stream, a reduction in ammonium-nitrogen was observed from $4.52 \pm 0.55 \mathrm{mg} / \mathrm{L}$ to $1.72 \pm 0.49 \mathrm{mg} / \mathrm{L}$ as shown by Fig. 3a. A similar trend was observed for phosphate-phosphorous, where the average influent phosphate concentration was $0.96 \pm 0.12 \mathrm{mg} / \mathrm{L}$ and reduced to $0.39 \pm 0.13 \mathrm{mg} / \mathrm{L}$ at the effluent, Fig. $3 \mathrm{~b}$.

\section{Discussion}

The natural treatment method involving green and environment-friendly techniques that use plants to remove contaminants from the environment and have attracted the attention
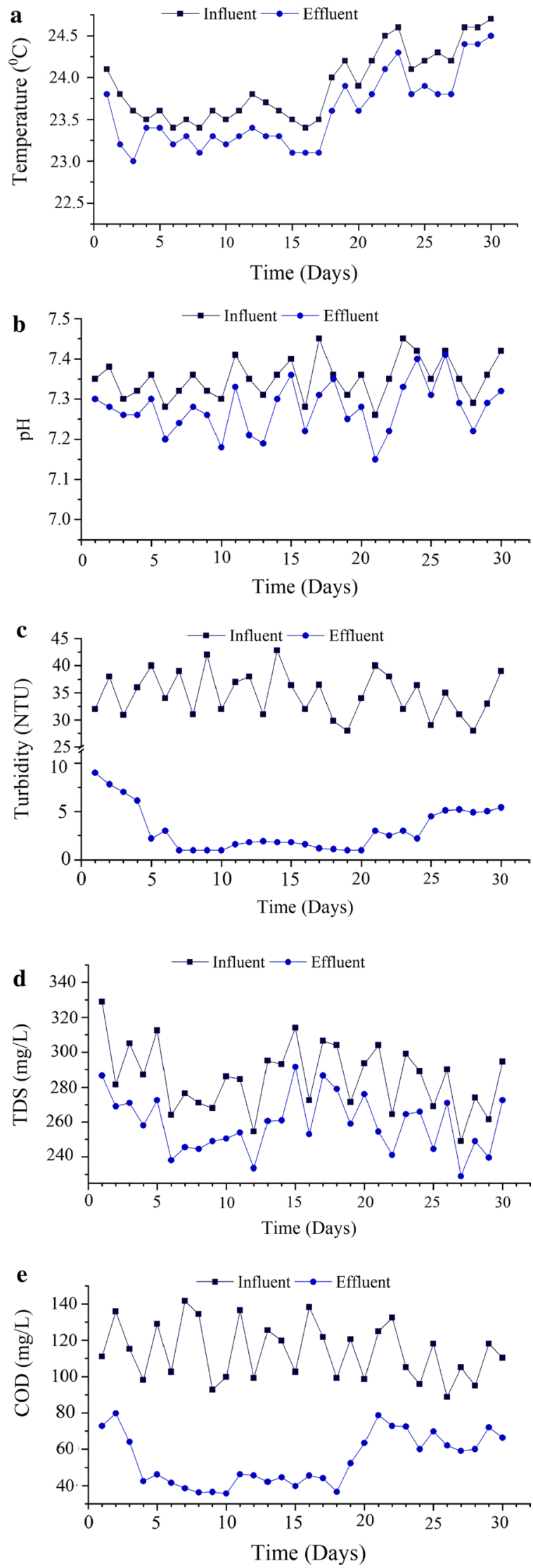

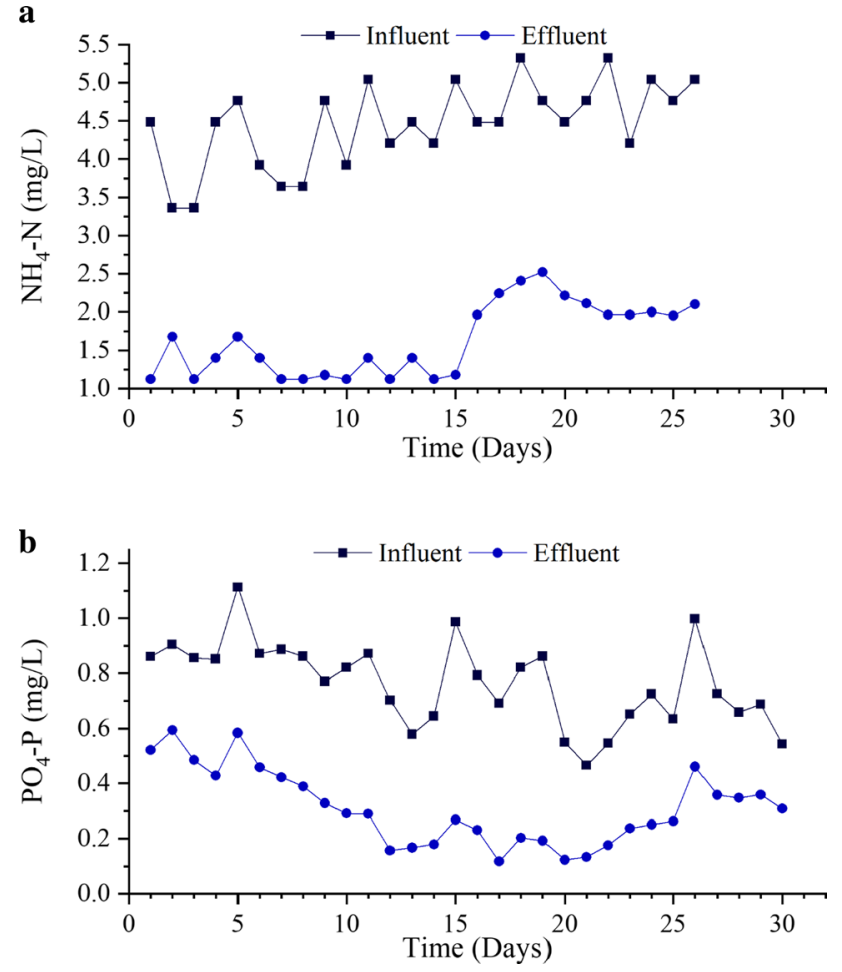

Fig. 3 Temporal variations in the influent and effluent greywater streams for $\mathbf{a}$ ammoniacal-nitrogen and $\mathbf{b}$ phosphate-phosphorous

of the environmentalist because of its high efficiency, low cost, and ease of harvest. In particular, aquatic plant-like ECP has a significant advantage over other plants due to its prolific growth and ease of harvest. Macrophytes with long and dense roots are essential for nutrients absorption and act as a media for intercepting and absorbing suspended particulate matter (Kim and Kim 2000). Characteristics of wastewater play a vital role in achieving higher removal in the phytoremediation process. Aquatic plants (ECP) are highly sensitive to the $\mathrm{pH}$ of the water and atmospheric temperature which controls the overall growth and removal of the nutrients. The $\mathrm{pH}$ and water temperatures were in the range of 6-9 and $15-38{ }^{\circ} \mathrm{C}$, respectively, considered appropriate for WH growth (Shah et al. 2014). Hence, water temperature throughout this study was varied between 23.1 and $24.7^{\circ} \mathrm{C}$. Vymazal (2007) reported a minimum temperature of $20^{\circ} \mathrm{C}$ for optimum performance, below which the rate of nitrification reduces until it reaches zero at $6{ }^{\circ} \mathrm{C}$. Hence, this study was carried out under appropriate temperature and $\mathrm{pH}$. Overall the experiment was carried out under optimal $\mathrm{pH}$ (7-8) suitable for nutrient absorption and biochemical reactions of the living organisms (Qin et al. 2016). The maximum increase in biomass production occurred at a $\mathrm{pH}$ of 5.8-7.5, leading to an increase in ECP nutrient uptake (Gupta et al. 2012; Ting et al. 2020). A decrease in the $\mathrm{pH}$ level of water is a limiting factor for biomass growth. The overall water temperature and $\mathrm{pH}$ were kept within the range for higher growth of ECP to result in high nutrients removal. Turbidity is the measure of suspended materials in water. In this study, the average removal of $90.68 \pm 7.01 \%$ and maximum removal of $97.62 \%$ were observed. The turbidity removal efficiency increased till the 20th day beyond which a reduction in removal efficiency was observed. Three mechanisms for turbidity reduction are possible interception, sedimentation, and filtration (Trang et al. 2010). In this study, the turbidity removal was mainly through physical mechanisms, the sedimentation process removed organic and inorganic particles resulting in the reduction of turbidity (Vymazal 2005). Similar results were obtained by (Rameshkumar et al. 2019). The TDS removal of $9.21 \pm 2.65 \%$ was observed in this study. It can be seen that a significant reduction was not observed $(p>0.005)$. It can be said that ECP does not participate in the removal of TDS (Munavalli and Saler 2009). A similar result was observed by Rezania et al. (2016) where only an $11 \%$ reduction in domestic wastewater treatment. Nitrogen removal takes place through combinations of uptake by the plant as a nutrient, consumption by microbes, adsorption, volatilization, nitrification, and denitrification. Among the various forms of nitrogen, ammonia removal was found to be the highest (Chen et al. 2010). The factors that had the most influence on the nitrification process were the dissolved oxygen level, temperature, and retention time. ECP exhibits the highest nitrification due to its dense fibrous root system. Ammonia removal depends on the $\mathrm{pH}$ and the temperature (Wallace and Knight 2006) but plant decay decreases the amount of dissolved oxygen level and thereby also affects the treatment performance. The removal performance observed in this study can be attributed to nitrification and the plant uptake through a welldeveloped rhizosphere. Aquatic plant species that increase DO concentrations most efficiently also show the highest nitrification rates. An average reduction of $62.15 \pm 09.08 \%$ was observed during the study period for this investigation. On the contrary, Fox et al. (2008) and Nahlik and Mitsch (2006) achieved $60 \%-85 \%$ and $40.34 \%$ respective reduction of ammonia nitrogen. The plant influences the denitrification rate by providing a large surface area for biofilms, thus providing a favorable environment needed for denitrifies (Sooknah 2000). From Fig. 3a, it can be seen that the continuous removal of ammonia was observed till the 15th day of treatment after which a reduction in the removal efficiency was observed. This period can be referenced to the start of decomposition of ECP litter which essentially released its absorbed nutrients back into the water. The decomposition process occurred when ECP stem and leaf were saturated due to maturity and not able to uptake nutrients for its survival resulting in its fall in the water stream leading to its litter and subsequent decomposition. To prevent the decomposition, the mature ECP should be removed. It is important

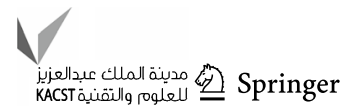


to note that while the mother plant matures at the same time baby plant (asexual growth) is in full growth phase requiring nutrients for its growth, survival, and development, hence, only the matured mother plant has to be removed. Phosphorous is an important nutrient for vegetative reproduction in plants and its growth. The phosphorous removal takes place through three main mechanisms: sorption, utilization by the plant for its growth, and refectory residual (burial). The major resource for phosphorous removal is through ECP vegetative and stolon growth with the latter being the dominant ECP growth pathway. The reduction in the phosphorous was through consumption by the plant and microorganisms as nutrients (Rangel-Peraza et al. 2019) filtration of particulate matter via roots and settling mechanism (Shah et al. 2014). The nutrition needs through stolon growth are met by the nutrients present in the greywater. Kadlec (2005) found that out of the total reported uptake by plant only $10 \%-20 \%$ is stored permanently in the residual and remaining returned into the water through the decomposition process. Thus, to prevent decomposition, the timely removal of ECP from the treatment system is critical. From this study, and in the present nutrient concentration the cycle of growth and decomposition of biomass occurred within 20 days of plantation and hence it is necessary to harvest the matured biomass by that time. Hence, the harvesting of biomass is important for the removal process to continue and become sustainable. In phytoremediation, plant productivity is directly related to the nutrient removal efficiency during the greywater treatment process. Also, nutrient removal efficiency depends on the operating conditions of contacting system, i.e., reactor. The productivity of macrophytes (floating) is higher than that of terrestrial and crops as they have adequate water supply (Shah et al. 2014). The roots of water hyacinth play an important role in the assimilation of nutrients for its growth and multiplication. The ECP has long and dense roots that are responsible for absorbing nutrients thereby act as media for intercepting and absorbing the suspended particulate matter (Qin et al. 2016). Rhizofiltration, a form phytoremediation, is the mechanism involved in the degradation and filtration of contaminants in greywater. Nutrients present in the greywater act as nutrition for plants essential for their growth. The growth rate is directly related to the nutrient removal capacity of the plant. ECP is an aquatic macrophyte having the potential to double its biomass within 7-15 days (Coetzee et al. 2014). Its higher productivity is directly related to the nutrient removal capacity. At first, when the plant is fresh, the nutrient uptake would be rapid, leading to higher nutrient removal rates relative to the mature plants. Hence, there is a need to harvest biomass regularly to obtain efficient removal continuously. An increase in biomass was measured at the beginning and the end of the experimental run. Initially, the biomass weight was $2 \mathrm{~kg}$, which increased to $3.5 \mathrm{~kg}$ resulting in a $75 \%$ increase in biomass during the study period. Qin et al. (2016), in their study of phytoremediation of domestic sewage, achieved a $52.52 \%$ increase in WH biomass in 30 days. In this study, the maximum nutrient uptake by ECP was observed by day 20 after which a reduction in the removal efficiency was observed, which can be attributed to the plant maturation. During the initial days of plant growth, the rate of nutrient uptake is generally higher to meet its growth demands, and after that, as the plant matures, the nutrient uptake reduces, and hence the nutrient removal efficiency also reduces as observed in this study. The optimal removal was obtained during the first 15-20 days in contrast to the result obtained by Shah et al. (2014) where the optimal period of harvesting was 8-10 days, whereas Rezania et al. (2016) reported optimal removal efficiency in 13-17 days for phytoremediation in municipal wastewater. The difference in the duration in these studies can be due to the variation in the nutrient concentration. Greywater generally has a lower level of a nutrient compared to municipal wastewater due to the separation of black water. This difference in nutrient level changes the growth rate and hence the duration of harvesting. The root and shoot length in 5 days intervals is presented in Fig. 4. Harvesting frequency is a key factor in effective phytoremediation using ECP (Ting et al. 2018). It preserves the balance between the biomass available and the nutrients to be removed. The harvested biomass can be used as mulch for transferring nutrients to the kitchen garden. The decay in the plant tissue after its useful life is a natural process that results in decomposition and consumption of a large amount of oxygen (Mishra and Maiti 2017) and hence hinders the phytoremediation process. Nahlik and Mitsch (2006) recommended $30 \%$ harvesting of biomass at a given time resulting in improved optimum nutrients removal throughout the treatment process. The challenge in this process is the nondiscriminatory harvesting of the baby plant along with mature mother plants putting the process at a disadvantage. The baby plant is typically attached to the mother plant through stolon, which initially supplies essential nutrients for growth and development. So, while removing the mother plant, the

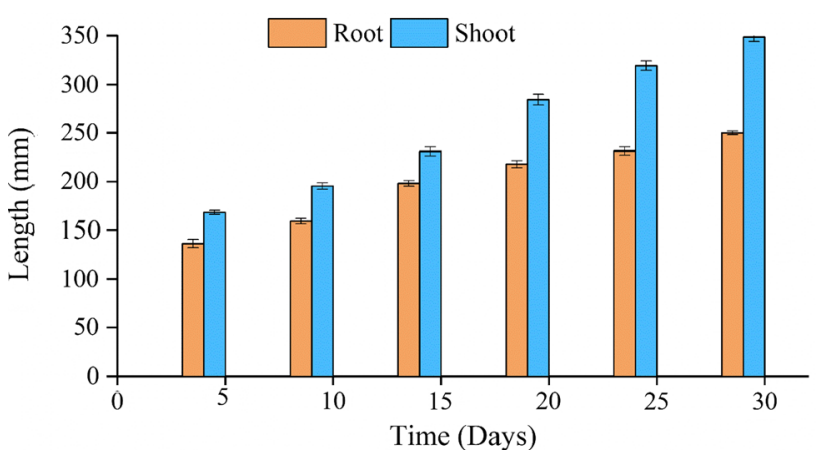

Fig. 4 Change in root and shoot length of ECP grown in greywater 
baby plant also gets accidentally removed. To avoid complete removal of mother and baby ECP, a method of harvesting needs to be studied and developed.

\section{Disposal options for ECP}

The use of Eichhornia crassipes plant (ECP) for greywater treatment provides the added value of the rapid production of ECP biomass. The proper disposal of nutrient-rich ECP is important to prevent further loss of nutrients in the environment. One of the economical and environmentally friendly disposal options of harvested ECP biomass is its conversion into nutrient-rich organic fertilizer. Other disposals or utilization options that are cost-intensive include its use as an adsorbent for dye removal (Prasad and Yadav 2020), biogas (Adanikin et al. 2017), bioethanol (Adanikin et al. 2017), composite (Flores Ramirez et al. 2015), a substrate for mushroom (Andrew et al. 2013), and briquette (Munjeri et al. 2016) production.

\section{Conclusions}

The current preliminary study on greywater treatment systems showed the treatment potential that can transform greywater to water that has reduced concentration of organic matter reusable for multiple purposes. The current study showed the efficacy of ECP as a greywater treatment agent with a significant reduction in COD (51.61 $\pm 13.56 \%)$, ammonium-nitrogen $(62.15 \pm 9.08 \%)$, and phosphate-phosphorous $(58.13 \pm 15.23 \%)$, turbidity $(90.68 \pm 7.01 \%)$, and other parameters like $\mathrm{pH}$ were 7.15-7.41, and TDS reduction was $9.21 \pm 2.65 \%$. The biomass content of ECP increased by $75 \%$ during the study duration. ECP was also capable to effectively reduce the nitrogen and phosphorous nutrient components for the treated greywater. The results show the proposed treatment system requires the harvesting of ECP after 15-20 days one stream for consistent and optimum treatment performance. After 20 days, the ECP plant starts to decay which leads to a reduction in the ECP treatment abilities and capacity for contaminants removal. The proposed treatment system is simple to operate, low energy, and requires minimal maintenance. Also, the process gives the additional benefit in terms of regular ECP biomass production, which can be used as a raw material to make fertilizer and other chemicals and biofuels. It is recommended that this preliminary study be furthered for a more comprehensive evaluation of other technical aspects such as optimum ECP density, hydraulic retention time, reactor design, TDS removal, long-term performance stability, and the process economics before it can be implemented at a larger scale.
Funding None. No funding to declare.

Declaration

Conflict of interest All authors have no conflict of interest to report.

Open Access This article is licensed under a Creative Commons Attribution 4.0 International License, which permits use, sharing, adaptation, distribution and reproduction in any medium or format, as long as you give appropriate credit to the original author(s) and the source, provide a link to the Creative Commons licence, and indicate if changes were made. The images or other third party material in this article are included in the article's Creative Commons licence, unless indicated otherwise in a credit line to the material. If material is not included in the article's Creative Commons licence and your intended use is not permitted by statutory regulation or exceeds the permitted use, you will need to obtain permission directly from the copyright holder. To view a copy of this licence, visit http://creativecommons.org/licenses/by/4.0/.

\section{References}

Adanikin BA, Ogunwande GA, Adesanwo OO (2017) Evaluation and kinetics of biogas yield from morning glory (Ipomoea aquatica) co-digested with water hyacinth (Eichhornia crassipes). Ecol Eng 98:98-104

Agarry SE, Oghenejoboh KM, Latinwo GK, Owabor CN (2018) Biotreatment of petroleum refinery wastewater in vertical surfaceflow constructed wetland vegetated with Eichhornia crassipes: lab-scale experimental and kinetic modelling. Environ Technol United Kingdom 41:1793-1813

Ahamed MI, Inamuddin L, Sharma G, Khan A, Asiri AM (2016) Turmeric/polyvinyl alcohol Th(IV) phosphate electrospun fibers: Synthesis, characterization and antimicrobial studies. J Taiwan Inst Chem Eng 68:407-414

Andrew N, Oima O, Oginda D (2013) Utilization of water hyacinth as an alternative substrate for mushroom farming: a study of vihiga mushroom project in western kenya. Int J Educ Res 1:1-10

Barkoula NM, Alcock B, Cabrera NO, Peijs T (2008) Flame-retardancy properties of intumescent ammonium poly(Phosphate) and mineral filler magnesium hydroxide in combination with graphene. Polym Polym Compos 16:101-113

Xi C, Xiuxia C, Wan X, Weng B, Huang Q (2010) Water hyacinth (Eichhornia crassipes) waste as an adsorbent for phosphorus removal from swine wastewater. Bioresour Technol 101:9025-9030

Cheng JJ, Stomp AM (2009) Growing duckweed to recover nutrients from wastewaters and for production of fuel ethanol and animal feed. Clean: Soil, Air, Water 37:17-26

Coetzee JA, Jones RW, Hill MP (2014) Water hyacinth, Eichhornia crassipes (Pontederiaceae), reduces benthic macroinvertebrate diversity in a protected subtropical lake in South Africa. Biodivers Conserv 23:1319-1330

Davies RM, Abolude DS (2013) Mechanical handling characteristics of briquettes produced from water hyacinth and plantain peel as binder. J Sci Res Rep 2:93-102

Dersseh MG, Melesse AM, Tilahun SA, Abate M, Dagnew DC (2019) Water hyacinth review of its impacts on hydrology and ecosystem services-Lessons for management of Lake Tana. Extreme Hydrol Climate Var 237:251

El-Gendy AS, Biswas N, Bewtra JK (2004) Growth of water hyacinth in municipal landfill leachate with different $\mathrm{pH}$. Environ Technol $25: 833-840$

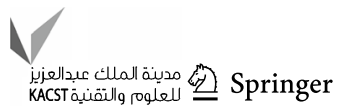


Flores Ramirez N, Sanchez Hernandez Y, Cruz de Leon J, Vasquez Garcia SR, Domratcheva Lvova L, Garcia Gonzalez L (2015) Composites from water hyacinth (Eichhornea crassipe) and polyester resin. Fibers Polym 16:196-200

Fox LJ, Struik PC, Appleton BL, Rule JH (2008) Nitrogen phytoremediation by water hyacinth (Eichhornia crassipes (Mart.) Solms). Water Air Soil Pollut 194:199-207

Friedler E, Hadari M (2006) Economic feasibility of on-site greywater reuse in multi-storey buildings. Desalination 190:221-234

Gajalakshmi S, Abbasi SA (2002) Effect of the application of water hyacinth compost/vermicompost on the growth and flowering of Crossandra undulaefolia, and on several vegetables. Bioresour Technol 85:197-199

Ganguly A, Chatterjee PK, Dey A (2012) Studies on ethanol production from water hyacinth-a review. Renew Sustain Energy Rev 16:966-972

Gao Y, Yi N, Wang Y, Ma T, Zhou Q, Zhang Z, Yan S (2014) Effect of eichhornia crassipes on production of $\mathrm{N} 2$ by denitrification in eutrophic water. Ecol Eng 68:14-24

Ghaitidak DM, Yadav KD (2014) Effect of coagulant in greywater treatment for reuse: selection of optimal coagulation condition using Analytic Hierarchy Process. Desalin Water Treat 55:913-925

Gupta P, Roy SB, Mahindrakar A (2012) Treatment of water using water hyacinth, water lettuce and vetiver grass-a review. Resour Environ 2:202-215

Hill DT, Payton JD (2000) Effect of plant fill ratio on water temperature in constructed wetlands. Bioresour Technol 71:283-289

Inamuddin IYA (2010) Synthesis and characterization of electrically conducting poly-o-methoxyaniline $\mathrm{Zr}(1 \mathrm{~V})$ molybdate $\mathrm{Cd}(\mathrm{II})$ selective composite cation-exchanger. Desalination 250:523-529

Jayaweera M, Kasturiarachchi JC (2004) Removal of nitrogen and phosphorus from industrial wastewaters by phytoremediation using water hyacinth (Eichhornia crassipes (Mart.) Solms). Water Sci Technol 50:217-226

Kadlec RH (2005) Phosphorus removal in emergent free surface wetlands. J Environ Sci Heal Part A Toxic/hazardous Subst Environ Eng 40:1293-1306

Kadlec RH, Wallace S (2009) Treatment Wetlands, Treatment Wetlands.

Kim Y, Kim WJ (2000) Roles of water hyacinths and their roots for reducing algal concentration in the effluent from waste stabilization ponds. Water Res 34:3285-3294

Mishra S, Maiti A (2017) The efficiency of Eichhornia crassipes in the removal of organic and inorganic pollutants from wastewater: a review. Environ Sci Pollut Res 24:7921-7937

Mohammad A, Inamuddin HS (2015) Poly (3,4-ethylenedioxythiophene): polystyrene sulfonate (PEDOT:PSS) Zr(IV) phosphate composite cation exchanger : sol-gel synthesis and physicochemical characterization. Ionics (kiel) 21:1063-1071

Munavalli GR, Saler PS (2009) Treatment of dairy wastewater by water hyacinth. Water Sci Technol 59:713-722

Munjeri K, Ziuku S, Maganga H, Siachingoma B, Ndlovu S (2016) On the potential of water hyacinth as a biomass briquette for heating applications. Int J Energy Environ Eng 7:37-43

Nahlik AM, Mitsch WJ (2006) Tropical treatment wetlands dominated by free-floating macrophytes for water quality improvement in Costa Rica. Ecol Eng 28:246-257

Oteng-Peprah M, Acheampong MA, DeVries NK (2018) Greywater characteristics, treatment systems, reuse strategies and user perception-a review. Water Air Soil Pollut 229:255
Prasad R, Yadav KD (2020) Use of response surface methodology and artificial neural network approach for methylene blue removal by adsorption onto water hyacinth. Water Conserv Manag WCM 4:73-79

Priya P, Nikhitha SO, Anand C, Dipin Nath RS, Krishnakumar B (2018) Biomethanation of water hyacinth biomass. Bioresour Technol 255:288-292

Qin H, Zhang Z, Liu M, Liu H, Wang Y, Wen X, Zhang Y, Yan S (2016) Site test of phytoremediation of an open pond contaminated with domestic sewage using water hyacinth and water lettuce. Ecol Eng 95:753-762

Rameshkumar S, Radhakrishnan K, Aanand S, Rajaram R (2019) Influence of physicochemical water quality on aquatic macrophyte diversity in seasonal wetlands. Appl Water Sci 9:1-8

Rangel-Peraza JG, Mendivil-García K, Cedillo-Herrera CIG, RochínMedina JJ, Rodríguez-Mata AE, Bustos-Terrones YA (2019) Optimization of organic matter degradation kinetics and nutrient removal on artificial wetlands using Eichhornia crassipes and Typha domingensis. Environ Technol (united Kingdom) 40:631-641

Rezania S, Din MFM, Taib SM, Dahalan FA, Songip AR, Singh L, Kamyab H (2016) The efficient role of aquatic plant (water hyacinth) in treating domestic wastewater in continuous system. Int J Phytorem 18:679-685

Shah M, Hashmi HN, Ali A, Ghumman AR (2014) Performance assessment of aquatic macrophytes for treatment of municipal wastewater. J Environ Heal Sci Eng 12:1-12

Sooknah R (2000) A review of the mechanisms of pollutant removal in water hyacinth systems. Univ Mauritius Res J 6:49-57

Sooknah RD, Wilkie AC (2004) Nutrient removal by floating aquatic macrophytes cultured in anaerobically digested flushed dairy manure wastewater. Ecol Eng 22:27-42

Ting WHT, Tan IAW, Salleh SF, Abdul Wahab N (2020) Ammoniacal nitrogen removal by Eichhornia crassipes-based phytoremediation: process optimization using response surface methodology. Appl Water Sci 10:1-11

Ting WHT, Tan IAW, Salleh SF, Wahab NA (2018) Application of water hyacinth (Eichhornia crassipes) for phytoremediation of ammoniacal nitrogen: a review. J Water Process Eng 22:239-249

Trang NTD, Konnerup D, Schierup HH, Chiem NH, Tuan LA, Brix H (2010) Kinetics of pollutant removal from domestic wastewater in a tropical horizontal subsurface flow constructed wetland system: Effects of hydraulic loading rate. Ecol Eng 36:527-535

Vymazal J (2007) Removal of nutrients in various types of constructed wetlands. Sci Total Environ 380:48-65

Vymazal J (2005) Horizontal sub-surface flow and hybrid constructed wetlands systems for wastewater treatment. Ecol Eng 25:475-490

Wallace S, Knight R (2006) Small-Scale Constructed Wetland Treatment Systems Feasibility, Design Criteria, and O\&M Requirements. IWA publishing, London

Publisher's Note Springer Nature remains neutral with regard to jurisdictional claims in published maps and institutional affiliations. 